\title{
Sources and methods of reconstruction of postal roads in the second half of the 18th century on the example of the former Lublin Voivodeship
}

\begin{abstract}
The subject of the article is reconstructing the routes of postal roads within the borders of the Lublin Voivodeship in the second half of the 18th century. The author has attempted to reconstruct the routes of postal roads, using the retrogression method and a cartographic research method with the use of GIS tools. For this purpose, manuscript cartographic and descriptive sources from the late 18th and 19th centuries were used. Cartographic material from the end of the 18th century in connection with descriptive sources constituted the basis for determining the existence of a postal connection. However, maps from the beginning of the 19th century constituted the basis for the reconstruction of the routes of postal roads. The obtained results allowed for the determination of the role of the Lublin Voivodeship in the old Polish communication system. The research has made us aware of the need for further in-depth work on communication in the pre-partition era (before 1795).
\end{abstract}

Keywords: postal roads, historical geography, historical GIS, retrogressive method, Lublin Voivodeship

\section{Introduction}

The author presents an attempt to reconstruct the routes of postal roads that were connected by royal post connections in the pre-partition borders of Lublin Voivodeship, based on handwritten cartographic and descriptive sources from the late 18th and early 19th centuries.

In the 18th century, the royal post was of a national and international character. Its functioning was financed by the state and served royal interests. A separate type of postal service was organized by some cities, poviats and voivodeships. These posts implemented local connections (J. Madej 1987). The issue of the functioning of the royal post, inseparably connected with postal roads, has only been outlined and is not subject to detailed analysis. The aspects related to the existence of road infrastructure (inns, bridges, crossings) were also briefly discussed.

\section{Sources and studies}

The source basis is divided into two main categories resulting from the typological diversity of sources:

- cartographic sources (handdrawings and printed);

- written sources (documentation, descriptive and statistical).

Karol Buczek (1930) claimed that maps constitute the dominant source with possibly accurate reconstruction of roads between settlement units. According to him, no text material can match this role (recreating the road network - the author's note) in comparison to the image contained in the cartographic communication, because using only written sources we are able to draw only a straight line (relatively broken) between two locations.

On the preserved pre-partition maps, postal roads were recorded on the occasion of pre- 
senting other communication elements. The first preserved map presenting postal connections in the studied area as the main content is the Karta dróg pocztowych Królestwa Polskiego (Map of postal roads of the Polish Kingdom) in $1820^{1}$. Another presenting the same area, but with a broader range of content (the distinction of roads into: large postal road, ordinary postal road, large individual road), is the Mappa Generalna Królestwa Polskiego z oznaczeniem pocztowych i partykularnych dróg, stacji i odległości mil między onemi (General map of the Polish Kingdom showing postal and major roads, stations and the distance in miles between them) published in St. Petersburg in 1820. The content of these maps is largely consistent with the information ${ }^{2}$ contained in sources concerning the second half of the 18th century. The mentioned maps, due to small scale and schematic presentation of connections, cannot serve as a source for reconstructing the routes of roads.

Due to the lack of postal maps, the Mappa szczegulna województwa lubelskiego (Map of the Lublin Voivodeship) by Carol Perthées at the 1:225,000 scale from 1786 deserves attention. A. Ertman (2007) pointed to the high value of this source for historical geography in the aspect of research, inter alia, on communication. This map, due to its high information value and lack of cartometry (B. Szady 2012), served only to determine the functioning of road connections. The reference cartographic source, which was used to determine the routes of roads and the localization of communication infrastructure facilities (bridges, inns, crossings, etc.), was a hand-written map of western Galicia by CoIonel Anton Mayer von Heldensfeld at the $1: 28,800$ scale made in 1801-1804 (L. Sawicki 1928, P. Cebrykow 2015). The source, which is chronologically close to the studied period, does not present any significant changes that resulted from the construction of roadways, marked on the Topograficzna Karta Królestwa Polskiego (Topographic Map of the Polish King-

\footnotetext{
1 This map is part of the publication by J. Krasiński Przewodnik dla podróżujących w Polsce i Rzeczpospolitej Krakowskiej (A guide for travelers in Poland and the Republic of Krakow), Warsaw 1821.

2 The convergence of information refers to the connections between postal stations and distances in miles between them.
}

dom, the so-called Quartermaster's Map) at the $1: 126,000$ scale, developed in 1822-1843. Significant changes should be understood as a new method of setting out roads. The administration of the partitioning powers introduced their own road construction patterns. Outside the towns, the routes were marked out with straight sections, ignoring the local development and ownership relations. The natural conditions were of greater significance, forcing, for example, the construction of dikes and detours (Z. Budzyński 2013).

Reconstructing the routes of postal roads, sources were not limited to maps only. Uncritical reasoning based on the content of old maps leads to incomplete or erroneous conclusions. The topics related to the analysis of old maps and their use in research on the cultural landscape have been the subject of numerous studies $^{3}$.

Written materials were also used to reconstruct postal routes. Diversified source basis results from the necessity to search for information dispersed in materials not only of different provenance, but also typology and time of creation. Documentation sources, such as Volumina Legum ${ }^{4}$ (further: Vol. Leg.), containing the record of all royal privileges and Sejm constitutions were used. Some of them were helpful in determining the legal factors of road functioning. The course of part of the routes was presented in Taryfa mostowego i grobelnego województwa lubelskiego (Tariffs for bridges and dikes in the Lublin Voivodeship) from 1767 (Z. Góralski 1956). In the description of postal connections operating in the studied area, press was used, focusing on "Dziennik Handlowy" (Trade Journal) $)^{5}$ published during the reign of King Stanisław August. The journal had a separate section devoted to land transport, in which information about the condition and maintenance of roads in the Polish-Lithuanian Commonwealth was

\footnotetext{
${ }^{3}$ A broader literature review can be found in selected publications: K. Nieścioruk 2004, B. Szady 2010, 2012; J. Nita, U. Myga-Piątek 2012.

${ }^{4}$ Volumina Legum, vols. 1-8, published by J. Ohryzko, St. Petersburg 1859-1860.

5 The full title of the journal: "Dziennik Handlowy zawierający w sobie wszystkie okoliczności czyli ogniwa całego łańcucha handlu polskiego. Zaczęty w Warszawie roku 1786" (Trade Journal containing all the circumstances or links of the entire chain of Polish trade. Started in Warsaw in 1786).
} 
published, and obtained, among others, from field correspondents. The analysis of Geograficzno-statystyczne opisanie parafiów Królestwa Polskiego w roku 1796 (Geographical and statistical description of parishes of the Kingdom of Poland in 1796) (further: Description of parishes) and statistical sources, such as Taryfy podymnego z dóbr w ziemi lubelskiej położonych (Roof tariffs for goods in the Lublin lands) from $1775,1777,1789,1790^{6}$ has a complementary nature.

Based on the above mentioned sources, researchers involved with roads carried out their research. Here, it is worth mentioning Geograficzno-statystyczne opisanie parafiów (Geographical and statistical description of parishes) known to Polish researchers mainly from the studies conducted by A. Krawczyk (1976), W. Wernerowa $(1994,1996)$ and A. Ertman (2007). The volume analyzed by the author refers to the area of the Kraków diocese, part of which until 1790 was the old voivodeship of Lublin (J. Kumor-Mielnik 2011). The content of the work indicates that it constituted the direct basis for the development of maps of voivodeships by C. Perthées (W. Wernerowa 1990). In research conducted for the purposes of this article, this source was not subject to a detailed and comprehensive analysis. The rich material included in the sketches was used to verify geographic and statistical information in relation to the location of significant communication elements (inns, bridges).

Literature on postal roads is not impressive, and a significant part of works is over 30 years old (a list of literature is given by J. Madej, 1987). Apart from the study of the roads of the Lublin Voivodeship in the second half of the 16 th century conducted by S. Wojciechowski $(1966)^{7}$ and a study known to a narrow group of researchers conducted by J. Teodorowicz-Czerepińska ${ }^{8}$, we do not have a broader study

\footnotetext{
${ }^{6}$ Materials included in the so-called Buczek's file. Scans available in the reading room of the Institute of History of the Polish Academy of Sciences in Warsaw.

${ }^{7}$ The study was carried out as part of work on Atlas historyczny Polski (Historical Atlas of Poland) and published in the form of a fascicle: Województwo lubelskie $w$ drugiej połowie XVI wieku (Lublin Voivodeship in the second half of the 16th century), by S. Wojciechowski, Warsaw 1966. The issue of the communication network was not the main topic of the study.

8 The study Główne trakty w międzyrzeczu Wisły i Bugu $X I I I-X V I w$. (Main routes in the intersection of the Vistula
}

of this issue in the analyzed area. There is also no comprehensive study of source materials regarding the organization and functioning of the post.

The subject of postal roads in the Polish era constituted the subject of research conducted by among others K. Piotrowski (1969), R. Skrycki (2003). Publications of L. Zimowski (1972a, b) have an important place in literature on the subject. The author of a synthetic study entitled Geneza i rozwój komunikacji pocztowej na ziemiach polskich (Genesis and development of postal communication in Poland) apart from organization of the post, also discusses postal roads. The problem of the functioning of these roads was also discussed by the authors of Atlas historyczny. Śląsk w końcu XVIII wieku (Historical atlas. Silesia at the end of the 18th century) (J. Wosch 1984). The eighteenth-century communication system, referring only to postal roads, was the subject of a monograph by J. Madej (1987). The bibliography of postal roads summarized in the article by $\mathrm{R}$. Zgorzelski (2008) is also noteworthy. The importance of the Lublin - Lvov route, including the existence of a postal route between these cities, is described in the article by A. Szykuła and J. Żygawski (2010). In turn, the subject of the communication system is discussed in detail in the article by A. Janeczek (2013). A valuable item from a methodological point of view is a book by M. Szilágyi (2014) about medieval roads in Hungary. The author presented literature referring to the issues of reconstructing the network of communication in selected European countries.

\section{Research methods}

The process of reconstructing the routes of postal roads was carried out using the retrogression method, because maps of communication systems, including postal ones, for the discussed period were not preserved (if there were any at all) (J. Madej 1987). The retrogression method was the effect of achievements related to the development of "Grundkartenforschung" by historical geographers conducting agrarian and historical studies and studies on

and the Bug in the 13th-16th centuries) (1997) implemented as part of works of the Regional Center for Research and Documentation of Monuments in Lublin. 
the sustainability of German village borders in the second half of the 19th century (B. Konopska 1994). The method of chronological comparisons, involving the establishment of earlier facts on the basis of later facts, has been widely used in Poland for nearly one hundred years and was presented by S. Arnold (1929). Theoretical foundations were discussed by T. Wąsowiczówna (1953, 1959, 1964). With regard to roads, this method has been discussed and developed in a practical way by subsequent researchers (H. Rutkowski 1973, A. Janeczek 2013).

The use of the retrogression method to reconstruct postal roads in the old Lublin Voivodeship consisted mainly in the use of source data, which allowed for the conclusion that postal roads could have been used in the period of interest. The analysis of chronological comparisons involved the selection of roads from the map of the Lublin Voivodeship by C. Perthées, the routes of which could be reconstructed based on among others the map by A.M. von Heldensfeld. It has been assumed that the large scale of the map of Western Galicia and the chronological proximity of the presented anthropogenic elements on both maps allows for the assumption of inertia of the routes of the roads. With regard to main roads, and postal roads should be considered as such, inertia is well grounded. After analyzing the aforementioned maps, it is noticeable that their functions change, while their routes do not.

An important research method in historical geography is a cartographic research method using GIS tools that facilitate spatial analysis. B. Szady wrote about it a decade ago (2008). Reconstructing the routes of postal roads, the concept of meta-object proposed by T. Panecki (2015) was adopted. Digitized road geometry has been assigned the attributes of the road category introduced from the maps: the map of the Lublin Voivodeship by C. Perthées, the map of Western Galicia by A.M. von Heldensfeld and the Quartermaster's map. The category "postal roads" from the map of the Lublin Voivodeship corresponded to the general road category from the map by A.M. von Heldensfeld. With this information, the most likely routes of roads in the second half of the 18th century were indicated.

\section{Characteristics of the postal road network in the Lublin Voivodeship}

The reign of King Stanisław August Poniatowski was of significant importance for the development of the post. At that time, this form of communication was reformed and gained a legal basis for functioning. A document that could be considered a constitution for the post was Instrukcja dla Ichmość panów pocztmagistrów poczt koronnych i W. Księstwa Litewskiego (Instructions for the Messrs of postmasters of the royal post and the post of Grand Duchy of Lithuania) published in December 1764 and applicable from January 1,1765 . This ordinance and instructions from the following years defined the tariffs for domestic and foreign letters (L. Zimowski 1972a, p. 93).

The reign of King Stanisław August is also the time of development of a network of roads and postal infrastructure ${ }^{9}$. At the main roads, new offices (post management offices) and postal substations (so-called posthalteries) were built. The state authorities appreciated the importance of roads as an important element of infrastructure serving the interests of the state. This is confirmed by attempts to centralize construction and maintenance of roads in the hands of the state, which is reflected in the decisions to support the repair of roads and bridges from 1764 and 1768 (L. Zimowski 1972a; Vol. Leg. vol. 7).

Plans and assumptions of royal policy in the face of weak and decentralized state power resulted in the lack of construction of roads even in neighboring countries. The references found in the source materials in a few cases relate only to road maintenance and repair (K. Piotrowski 1969). The change in the approach to the maintenance of postal roads is noticeable in the royal order from 1777 , and then in the Universal Act of February 11, 1782. This was connected with the imposition of the obligation to maintain postal routes on landowners. Due to the fact that they run inns located near postal roads, they were interested in maintaining these roads in good condition. In addition, the legislation allowed for the possibility of changing the routes of postal roads due to

\footnotetext{
${ }^{9}$ The issue of communication infrastructure on maps was the subject of, among others, the article by T. Bogacz and B. Konopska (2014).
} 
the improper level of road quality maintenance (L. Zimowski 1972a). In the materials included in the Popiel's collection ${ }^{10}$ there are a number of examples that show that the obligation to repair postal roads is being met. It can therefore be presumed that postal roads were maintained in relatively good condition, compared to other main roads (highroads).

Maintenance of postal roads consisted of temporary repairs involving filling potholes and cracks, repairing dikes and bridges. Roads led through wetlands were drained by digging drainage ditches (K. Piotrowski 1969). Postal roads were not very wide; the Lublin Sejm of 1569 set the width of the roads to 6 meters, which was to allow the passing of two carts (H. Rutkowski 1973). It seems that the poor quality of roads was the cause of problems related to passing. Confirmation of this supposition can be found in the royal order from 1777 imposing the obligation to give way to the post, simultaneously making available the side with a better surface. Additional facilitations resulted also from the provisions of the extraordinary Warsaw Sejm order from 1775, according to which couriers, relays and post offices gained the right to pass through bridges at any time of the year and day (K. Piotrowski 1969, Vol. Leg. vol. 8).

In the 18th century, Lublin was the capital of the voivodeship and served as a regional postal node. Deliveries made by post called according to the names of individual lands arrived there:

- Russian post (connections with selected larger cities: Zamość, Lvov, Stanisławów, Kamieniec Podolski - further to Jass and Instanbul);

- Lithuanian post (with Brest, Grodno, Vilnius, Mogilev);

- Polish post (including Kraków);

- extraordinary post (with Włodzimierz, Łuck, Dubno, Ostrog) (L. Zimowski 1972a).

For communication the connection with War-

10 The material collected in the Central Archives of Historical Records. The "Popiel's Collection" is the result of the personal work of the office of Stanisław August. An important resource is a set of constitutions and their projects and other documents regarding Sejms under the reigns of August III (from 1744) and Stanisław August. Volume 299 containing Zbiór papierów należących do Interesów Poczt Jego Kr. Mci y Rzpltej Polskiej a 1765.01.14 ad 1779.04.27 (Collection of documents belonging to the interests of the Posts of His Royal Highness of the Republic of Poland) is extremely important (http://www.agad.gov.pl/inwentarze/ ZbPopiel12.xml\#idm1568229056 (access 17.10.2018). saw, which fulfilled the role of the central node in the service of postal connections, was important. Shipments were delivered on a weekly basis twice a week in both directions ${ }^{11}$. Shipments sent in the Lublin region arrived in Warsaw on Wednesday, and in the opposite direction they were sent on Thursdays and arrived on Sunday in Lublin (L. Zimowski 1972).

Confirmation of most of the above-mentioned connections can be found in the list of postal stations ${ }^{12}$ from 1767 included in the Popiel's Collection and in sources and materials from the period under consideration ${ }^{13}$.

Literature on the subject indicates the importance of Lublin as a place where the latitudinal routes from Russia to Pomerania and the meridian routes from Mazovia and Lithuania to Kraków intersected (T. Wąsowiczówna 1957). At the turn of the 14th and 15th centuries, the importance of Lublin grew, which advanced from a small border city to the group of ten major cities in Poland, becoming one of the most important centers of long-distance trade in Central Europe (R. Szczygieł 2005).

Confirmation of the role of Lublin as an important node is reflected in the route of postal roads (fig. 1). Through the area of the old Lublin Voivodeship, there were postal routes in the following directions:

- A route from Lublin to Warsaw (within the Warsaw route) measuring 24 Polish miles ${ }^{14}$. The road within the Lublin Voivodeship had the following route - from Lublin to Markuszów (4 miles), and then to Puławy (3 miles). According to the information contained in Taryfa mostowego i grobelnego z 1767 (Tariffs for bridges and dikes from 1767) it was a route of

\footnotetext{
11 This principle also functioned in Silesia. (Atlas historyczny Polski. Śląsk w końcu XVIII wieku (The historical Atlas of Poland. Silesia at the end of the 18th century), (J. Wosch 1984).

12 A map based on this list showing a diagram of postal connections is provided in the article by K. Piotrowski (1969).

${ }^{13}$ A full list of source materials was provided by L. Zimowski (1972a), and confirmed by J. Madej (1987). These include, inter alia, "Walne trakty w Koronie, w Litwie y w Prusiech" ("General tracts in the Crown, Lithuania and Prussia") published in 1771. Information about connections also appears on the pages of the above-mentioned "Dziennik Handlowy" and in sources located in the AGAD in the Popiel's Collection.

${ }^{14}$ Measures this period, including the Polish mile, were discussed by E. Stamm (1938). A Polish mile had three lengths: small one - around $6.250 \mathrm{~m}$, medium - $7.030 \mathrm{~m}$ and large $-7.810 \mathrm{~m}$.
} 
national importance (Z. Góralski 1956). The detailed route of the road is presented in "Description of parishes" from 1796 by C. Perthées. This route is shown in figure 1.

- The route from Lublin to Kamieniec Podolski (within the Lublin route). The road led to Piaski (3 miles), and further to Krasnystaw (3 miles). The route to Piaski is marked as nationwide, and further as "connecting the Lublin Voivodeship with the neighboring voivodeship"15.

- The route from Lublin to Kraków. The road led to Bełżyce (3 miles), then to Urzędów (3 miles) and to the border of the voivodeship in Rachów. In the data contained in "Dziennik Handlowy" there is no post station in the last town. It is, however, marked on the map of the Lublin Voivodeship by $\mathrm{C}$. Perthées and on later postal maps $^{16}$. It should be also noted that the connection between Bełżyce and Urzędów is not included in the tariff from 1767 . The source determines the connection between Lublin and Bełżyce as a local route (Z. Góralski 1956). Also, "Description of parishes" (C. Perthées 1796) does not represent a direct connection between these locations. This representation of the communication network on the described section is significantly different from the content of other maps ${ }^{17}$. It gives rise to the assumption that this road in the discussed section had the function of a state postal connection.

- The route from Lublin to Brest. Both in "Dziennik Handlowy" (1786) and the tariffs from 1767 (Z. Góralski 1956) there is no information about the Lublin - Brest route. The postal route is marked on the map of the Lublin Voivodeship,

15 According to the legend to Schemat sieci drożnej według Taryfy woj. lubelskiego z $1767 \mathrm{r}$. (Diagram of a road network according to the Tariffs for the Lublin Voivodeship from 1767) (Z. Góralski 1956).

16 The postal station in Rachów is noted, inter alia, on the postal maps from 1820 mentioned earlier.

17 The Lublin - Bełżyce - Urzędów connection as a significant road (postal) connection is shown on the following maps: Carte de la Pologne by Rizzi Zannoni at the 1:690,000 scale from 1772, Carte generale et itineraire de Pologne by Karol Perthées at the 1:5,200,000 scale from 1773, Mapa województwa lubelskiego (Map of the Lublin Voivodeship) by Karol Perthées at the 1:225,000 scale from 1786 and on later postal maps: Karta dróg pocztowych Królestwa Polskiego (Map of postal roads of the Kingdom of Poland) from 1820 and Mapa Generalna Królestwa Polskiego z oznaczeniem pocztowych i partykularnych dróg, stacji i odległości mil między onemi (The General Map of the Kingdom of Poland with the designation of postal and particular roads, station and distance in miles between them) from 1820.
Polonia and Carte générale et itineraire de Pologne by Carol Perthées (J. Madej 1987). In the listed sources, the postal station on this section was not marked ${ }^{18}$. In the Popiel's Collection there is information about the efforts of Sapieha concerning cancellation of the decision to move the postal station from Łęczna (K. Piotrowski 1969), which could confirm the fact of the existence of the postal station. Finally, the route of the road was assumed according to the map of the Lublin Voivodeship by C. Perthées.

Postal roads in the studied area were almost $200 \mathrm{~km}$ long. This number corresponds to the distances of sections presented by sources from the region. The Puławy - Lublin route had 7 miles ("Dziennik Handlowy" 1786). Assuming that the average mileage was $7.030 \mathrm{~m}$ (E. Stamm 1938), this gives a distance of $49.2 \mathrm{~km}$. In "Description of parishes", the distance was about 6 miles. Assuming the length of a mile as 8,238 m (E. Stamm 1935, W. Wernerowa 1993) it gave $49.4 \mathrm{~km}$. The numbers given in the sources were confronted with the geometry of the reconstructed routes of postal roads. The length of the Puławy - Lublin route in a spatial database is $49.3 \mathrm{~km}$.

In the second half of the 18th century, there were eight postal stations in the Lublin Voivodeship $^{19}$ in the following towns: Rachów, Bełżyce, Lublin, Markuszów, Piaski, Puławy, Urzędów, Łęczna. The legislation at that time provided for the distribution of postal stations in the Crown area every 2-4 Polish miles. This assumption seems to be met in the discussed area. The average distance between postal locations was 3-4 miles. Such arrangement of the stations enabled the post to travel the route between three stations within 24 hours. According to K. Piotrowski (1969), the average daily course of the post in the years 1733-1754 ranged from 16 Polish miles on the Warsaw Kraków route, to 7.14 miles (about $51 \mathrm{~km}$ ) on the Warsaw - Lvov route in the Lublin Voivodeship. The time of covering the route was dependent on the importance of the route, and hence the technical condition of the road. Relatively short distances traveled over a 24-hour period

\footnotetext{
${ }^{18}$ Literature is dominated by the statement that roads towards Polesie were of secondary importance $(\mathrm{H}$. Maruszczak 2004). This may indicate potential deficiencies of the map.
}

${ }^{19}$ Assuming that there was a post station in Łęczna. 


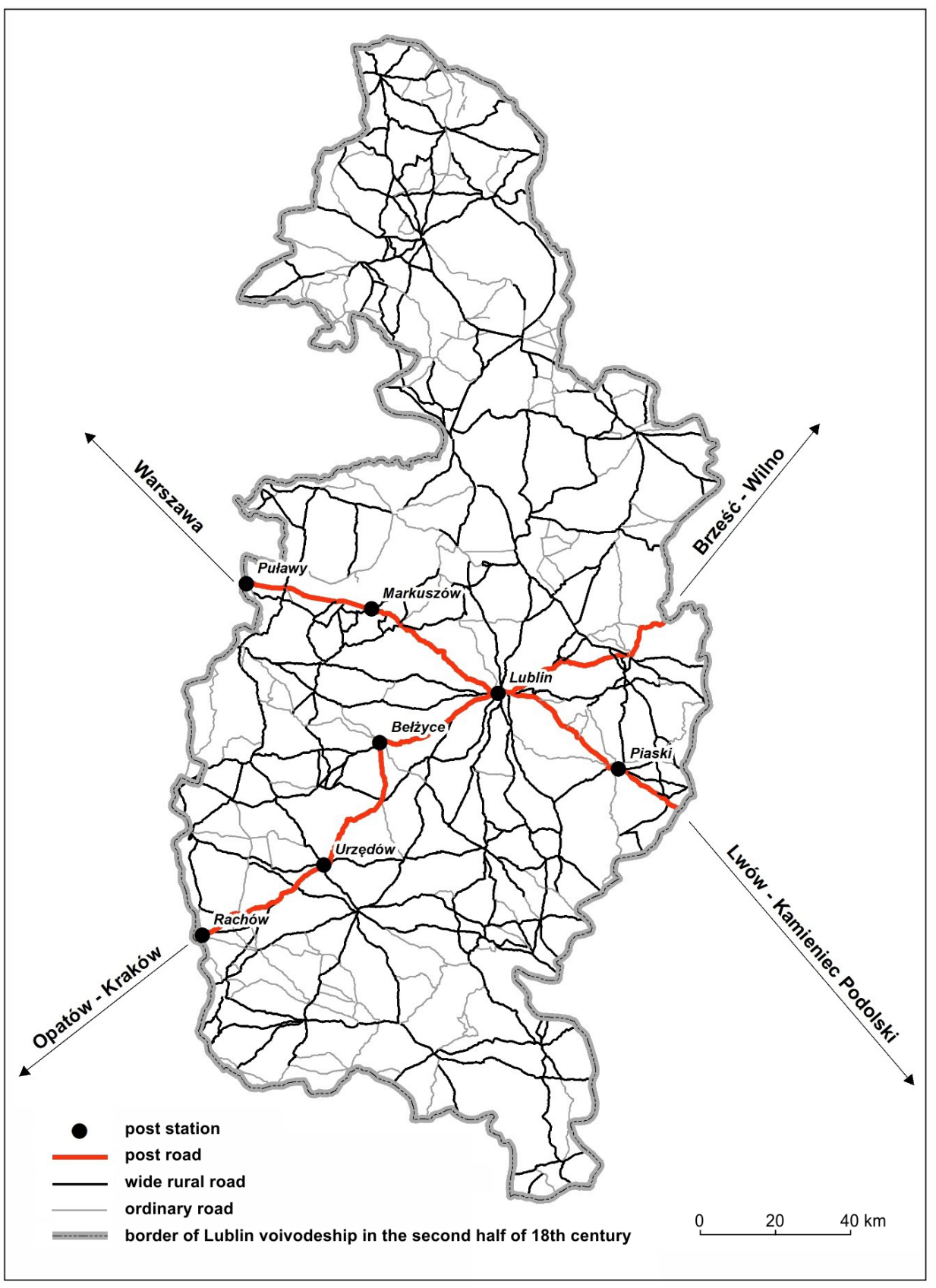

Fig. 1. Map of postal roads considering the communication network of the Lublin Voivodeship in the second half of the 18th century (the author's elaboration) 
in the Lublin Voivodeship may indicate low quality of roads compared to other parts of the country.

Implementing the connection on the Warsaw - Lublin route, the post had to cross the Vistula between Góra and Puławy. According to cartographic sources as well as bridge and dike tariffs, there was a ferry crossing (Z. Góralski 1956). On the Puławy - Lublin route, seven water obstacles were overcome by the post (including rivers: Kurówka, Białka and Ciemiega twice). The Lublin - Krasnystaw route (to the border of the voivodeship) intersected two rivers (Bystrzyca, Giełczewka), as well as three streams. The postal route from Lublin to Kraków (up to the border of the voivodeship on the Vistula) crossed three rivers (Chodelka, Urzędówka, Wyżnica) and three streams.

Small rivers and streams were overcome by wooden bridges, the construction of which sometimes consisted only of logs placed between banks of rivers and streams. These constructions were not recorded in the 1767 tariff. Larger obstacles required support bridges (W. Szulta 2008). Twenty-three bridges were identified on the postal routes. Their length depended on terrain obstacles and was 16 cubits $^{20}(9.5 \mathrm{~m})$ on the Sierotka ${ }^{21}$ stream near Piaski, up to $500 \mathrm{cu}$ bits $(298 \mathrm{~m})$ through the valley of the Ciemięga river (Z. Góralski 1956).

On larger and deep rivers like the Vistula River, the crossing took place using rafts with time replaced by ferries (L. Zimowski 1972a). The crossing locations were marked on old maps in the form of symbols or inscriptions. On the map of the Lublin Voivodeship by C. Perthées, there is an inscription Przewóz ("Transfer"), crossing the Vistula river between Jozefów and Tarłowo. Symbols - a boat or a raft - were used on the topographic map by A.M. von Heldensfeld and on Topograficzna Karta Królestwa Polskiego (Topographic Map of the Kingdom of Poland).

Crossings through wetlands and swampy lands were difficult especially for travelers traveling by carts. Dikes were built to overcome these obstacles. Ten dikes were identified on the routes of postal roads ( $Z$. Góralski 1956). In $90 \%$ of cases, a dike as a communication device functioned in connection with

\footnotetext{
201 Warsaw cubit $=595.5 \mathrm{~mm}$ (Z. Góralski 1956).

21 Today's name of the watercourse based on the Topographic Object Database.
}

a bridge. Depending on the terrain obstacle, diverse materials were used to build them. The analyzed sources, in most cases, do not provide information about dike building material. With a high probability, these were earth structures reinforced with wood (W. Szulta 2008). Structures of construction rubble, stone and wood (branches) were also used (Z. Góralski 1956). The matters of construction and maintenance of the dikes were recorded in the Sejm constitutions (K. Piotrowski 1969).

Roadside inns constituted an important element of the road infrastructure. Usually located outside dense settlements, often in the depths of forests or at the intersections of roads, they were necessary for long-distance travels at that time. A large number of them along a road can be a sign of the high rank of the route and its frequent use. This is confirmed by the route between Puławy and the eastern border of the voivodeship, amounting to $91 \mathrm{~km}$. In the second half of the 18th century, there were 12 inns on this section (according to the map of the Lublin Voivodeship). On average, there was an inn every Polish mile $(7.6 \mathrm{~km})$. The route was a part of the Warsaw - Kamieniec Podolski connection, which was the longest postal connection in the Polish-Lithuanian Commonwealth, and at the same time serving as an international connection. The rank of this road is noticeable when analyzing sources from the era. Fragments of the route in "Description of parishes" (C. Perthées 1796) are presented with a double line or with the annotation "large highroad".

\section{Conclusion}

The result of the research is the presentation of the routes of postal roads in the Lublin Voivodeship within the pre-partition borders. This task was carried out using cartographic and written sources. In the absence of cartometric sources from the era, the retrogression method was applied. A broad range of data obtained in the digitization process required the use of GIS tools. The developed geographical database (road geometry, location of communication devices: bridges, dikes, inns, postal stations) allowed in-depth studies to be conducted on the basis of the materials gathered in it. The map of postal roads of the Lublin Voivodeship (fig. 1) indicates their transit role in state communication. 


\section{Literature}

Arnold S., 1929, Geografia historyczna, jej zadania i metody. „Przegląd Historyczny” T. 28, nr 1, pp. 91-120.

Bogacz T., Konopska B., 2014, Infrastruktura szlaków komunikacyjnych na mapach Śląska z XVIII i XIX wieku. In: T. Głowiński, R. Klementowski (eds.), Na lądzie, wodzie $i$ w powietrzu... Z dziejów transportu i komunikacji na ziemiach polskich na przestrzeni wieków. Wrocław: Wydawnictwo GAJT, pp. 11-22.

Buczek K., 1930, Mapa województwa krakowskiego z doby sejmu czteroletniego (1788-1792). Źródła i metoda. Kraków: Polska Akademia Umiejętności.

Budzyński Z., 2013, Cesarskie gościńce w Galicji. Pierwszy etap budowy sieci dróg bitych (wg mapy józefińskiej Fryderyka Miega). In: J. Kamińska-Kwak (ed.), Galicyjskie drogi i bezdroża. Studium infrastruktury, organizacji i kultury podróżowania. Rzeszów: Wydawnictwo Uniwersytetu Rzeszowskiego, pp. 25-58.

Cebrykow P., 2015, Dawne mapy topograficzne Lubelszczyzny jako źródła informacji $w$ badaniach historyczno-geograficznych (Early topographical maps of Lublin region as information sources in historical-geographical studies). In: A. Czerny (ed.), Dawne mapy topograficzne w badaniach geograficzno-historycznych (Early topographical maps in geographical-historical studies). Lublin: Wydawnictwo UMCS, pp. 85 - 102. Available online at: http://phavi.umcs.pl/at/attachments/2016/0708/ 103742-czernydawne-mapy-07-07-low-res.pdf

„Dziennik Handlowy, zawierający w sobie wszystkie okoliczności czyli ogniwa całego łańcucha handlu polskiego. Zaczęty w Warszawie roku 1786". Available online at: http://pbc.biaman.pl/dlibra/docmetadata? id=35\&from=publication

Ertmann A., 2007, Rękopiśmienna mapa województwa podlaskiego Karola Perthéesa z r. 1795. Jej źródła, metoda opracowania i znaczenie dla badań historycznych. „Analecta”, T. 16, nr 1-2, pp. 129-137.

Góralski Z., 1956, Taryfa mostowego i grobelnego województwa lubelskiego z 1767 r. „Kwartalnik Historii Kultury Materialnej” nr 3/4, pp. 541-574.

Janeczek A., 2013, Staropolski układ komunikacyjny na mapie józefińskiej Galicji z lat 1779-1783. Szansa czy iluzja rekonstrukcji. In: J. Kamińska-Kwak (ed.), Galicyjskie drogi i bezdroża. Studium infrastruktury, organizacji i kultury podróżowania. Rzeszów: Wydawnictwo Uniwersytetu Rzeszowskiego, pp. 9-24.

Konopska B., 1994, Polskie atlasy historyczne koncepcje $i$ realizacje. Warszawa: Wydawnictwo Retro-Art.

Krasiński J., 1821, Przewodnik dla podróżujących w Polsce i Rzeczpospolitej Krakowskiej. Warszawa: Drukarnia N. Glücksberga.
Krawczyk A., 1976, Carol Perthées "Descriptions of parishes" - a source for the historical geography and economic history of central eastern Poland in the late XVIIIth century (introductory information). „Zeszyty Naukowe UJ. Prace Geograficzne” T. 43, pp. 191-196.

Kumor-Mielnik J., 2011, Geografia historyczna Kościoła lubelskiego. In: H. Gapski (ed.), Atlas historyczny (archi)diecezji lubelskiej 1805-2005, Lublin, Towarzystwo Naukowe KUL, pp. 44-87.

Madej J., 1987, „Polonia... 1770” Karola de Perthéesa na tle osiemnastowiecznej kartografii polskiej i krajów ościennych. Warszawa: Biblioteka Narodowa.

Maruszczak H., 2004, Podziały geograficzne Europy i problemy pogranicza Słowiańszczyzny zachodniej i wschodniej. In: H. Maruszczak, Z. Michalczyk (eds.), Geograficzne problemy pogranicza Europy Zachodniej i Wschodniej, Lublin: Wydawnictwo Uniwersytetu Marii Curie-Skłodowskiej, pp. 9-30.

Nieścioruk K., 2004, Z metodyki badania map dawnych. „Annales UMCS” Vol. 59, Sec. B, pp. 273-281.

Nita J., Myga-Piątek U., 2012, Rola GIS w ocenie historycznych opracowań kartograficznych na przykładzie Wyżyny Częstochowskiej. „Prace Komisji Krajobrazu Kulturowego" Nr 16, pp. 121-141.

Panecki T., 2015, Modelowanie obiektów topograficznych w bazach danych historycznych. „Acta Universitatis Lodziensis. Folia Geographica Socio-oeconomia", Vol. 21, pp. 37-51.

Perthées C., 1796, Geograficzno-statystyczne opisanie parafiów Królestwa Polskiego, T. 1.

Piotrowski K., 1969, O drogach pocztowych i transporcie poczt w Polsce w wiekach XVI-XVIII. „Studia i Materiały do Dziejów Nauki Polskiej. Seria D, Historia techniki i nauk technicznych" T. 5, pp. 3-17.

Rutkowski H., 1973, Drogi. In: W. Pałucki (ed.), Atlas historyczny Polski. Mazowsze w drugiej połowie XVI wieku. Warszawa: Polska Akademia Nauk.

Sawicki L., 1928, Pułkownika Antoniego Barona Mayera von Heldensfeld zdjęcia topograficzne w Polsce w latach 1801-1804. Kraków: Księgarnia Geograficzna „Orbis”.

Skrycki R., 2003, Drogi pocztowe Nowej Marchii w wybranych dziełach kartograficznych XVIII wieku. „Nadwarciański Rocznik Historyczno-Archiwalny” Nr 10, pp. 113-122.

Stamm E., 1935, Miary długości w dawnej Polsce. „Wiadomości Służby Geograficznej” T. 3, pp. 3-33.

Stamm E., 1938, Staropolskie miary. Miary długości i powierzchni. Warszawa: Główny Urząd Miar.

Szady B., 2008, Zastosowanie systemów informacji geograficznej w geografii historycznej. „Polski Przegląd Kartograficzny” T. 40, nr 3, pp. 279-283.

Szady B., 2010, Granice powiatu łukowskiego w II połowie XVIII wieku - model liniowy $i$ sieciowy. In: A. Barańska, W. Matwiejczyk (eds.), Narrata de 
fontibus hausta. Studia nad problematyką kościelną, polityczną i archiwistyczną ofiarowane Janowi Skarbkowi w siedemdziesiątą rocznicę urodzin. Lublin: RW KUL, pp. 831-845.

Szady B., 2012, Mapa województwa lubelskiego Karola Perthéesa z 1786 roku jako źródło kartograficzne i historyczne. In: B. Konopska (ed.), Dawne mapy jako źródła historyczne. „Biblioteka Polskiego Przeglądu Kartograficznego” T. 3, pp. 26-35.

Szczygieł R., 2005, Lublin czasów renesansu i baroku. Gospodarczy, polityczny i kulturalny wizerunek miasta. „Annales UMCS” Vol. 23, Sec. FF, pp. 11-20.

Szilágyi, M., 2014, On the Road: The history and archaeology of medieval communication networks in East-Central Europe. Budapest: Archaeolingua Alapítvány.

Szulta W., 2008, Przeprawy mostowe na ziemiach polskich w średniowieczu. Toruń: Towarzystwo Naukowe w Toruniu.

Szykuła A., Żygawski J., 2010, Szlak Lwów - Lublin. Geneza, zmiany przebiegu i funkcje do końca XIX wieku. In: H. Łaszkiewicz (ed.), Ziemiaństwo na Lubelszczyźnie IV. Ziemianie w podróży. Materiały IV sesji naukowej zorganizowanej w Muzeum Zamoyskich w Kozłówce $w$ dniach 8-10 października 2008 roku. Lublin: Wydawnictwo Werset.

Wąsowiczówna T., 1953, W sprawie metody badań przebiegu wczesnośredniowiecznych dróg lądowych Polski. „Przegląd Zachodni” T. 9, nr 9-10, pp. 310-320.

Wąsowiczówna T., 1957, Wczesnośredniowieczne przeprawy przez środkową Wisłę. „Kwartalnik Historii Kultury Materialnej” T. 5, nr 3, pp. 433-453.

Wąsowiczówna T., 1959, Research on the mediaeval road system in Poland. "Archaeologia Polona” Vol. 2, pp. 125-140.

Wąsowiczówna T., 1964, Uwagi w sprawie badań nad siecią drożną wczesnośredniowiecznej Małopolski. In: W. Antoniewicz, P. Biegański (eds.), III Konferencja naukowa w Warszawie 13 i 14 kwietnia 1962. Referaty i dyskusje, Warszawa, pp. 57-66.

Wernerowa W., 1990, Opisy parafii dekanatu knyszyńskiego z roku 1784. "Studia Podlaskie” T. 1, pp. 99-205.

Wernerowa W., 1993, Opisy parafii dekanatu augustowskiego z 1784 roku. "Studia Podlaskie” T. 4, pp. 161-239.

Wernerowa W., 1994, Rękopiśmienne opisy parafii litewskich z 1784 roku. Dekanat grodzieński. Warszawa: Wydawnictwo Instytutu Historii Nauki PAN.
Wernerowa W., 1996, Rękopiśmienne opisy parafii litewskich z 1784 roku. Dekanat knyszyński i dekanat augustowski. Warszawa: Wydawnictwo Instytutu Historii Nauki PAN.

Wojciechowski S., 1958, Zbigniew Góralski, „Taryfa mostowego i grobelnego województwa lubelskiego z 1767 r.”. „Rocznik Lubelski” T. 1, pp. 252-255.

Wojciechowski S., 1966, Drogi. In: W. Pałucki (ed.), Atlas historyczny Polski. Województwo lubelskie w drugiej połowie XVI wieku. Warszawa: Polska Akademia Nauk.

Wosch J., 1984, Drogi. In: J. Janczak (ed.), Atlas historyczny Polski. Śląsk w końcu XVIII wieku. T. 2, Wrocław: Zakład Narodowy im. Ossolińskich, Wydawnictwo PAN.

Zimowski L., 1972a, Geneza i rozwój komunikacji pocztowej na ziemiach polskich. Warszawa: Wydawnictwo Komunikacji i Łączności.

Zimowski L., 1972b, Poczta wielkopolska w XVIII wieku. Drogi i połączenia pocztowe. „Zeszyty Naukowe UAM. Historia” T. 75, nr 12, pp. 71-85.

Zgorzelski R., 2008, Z badań nad historią dawnej poczty polskiej. Na marginesie pracy Tomasza Sumy, Urzędnicy pocztowi w Królestwie Polskim 1815-1871. Słownik biograficzny (Warszawa: Wydawnictwo DiG, 2005). „Klio. Czasopismo poświęcone dziejom Polski i powszechnym" Vol. 10, pp. 145-154.

Związek T., Panecki T., 2017, Osadnictwo olęderskie w badaniach nad rekonstrukcją szesnastowiecznego zalesienia na przykładzie okolic Nowego Tomyśla. „Studia Geohistorica” Vol. 7, pp. 29-62.

\section{Cartographic sources}

Mappa szczegulna województwa lubelskiego, 1786, Karol Perthées, 1:225,000, printed 1806, Paris.

Karte von Westgalizien, 1801-1804, Anton Mayer von Heldensfeld, 1:28,800, Wien.

Karta dróg pocztowych Królestwa Polskiego An. 1820, author unknown, about 1:2,270,000, Drukarnia N. Glücksberga, Warszawa.

Mappa Generalna Królestwa Polskiego z oznaczeniem pocztowych i partykularnych dróg, stacji i odległości mil między onemi., 1820, Piadyszew, 1:1,680,000, St. Petersburg.

Topograficzna Karta Królestwa Polskiego, 1822-1843, Karol Richter, 1:126,000, Warszawa. 